\title{
Intracranial solitary chondroma
}

\author{
Case report
}

Tunçalp Özgen, M.D., M. Necmettin Pamir, M.D., NeJat Akalan, M.D., Vural Bertan, M.D., and BehSan ÖNOl, M.D.

Departments of Neurosurgery and Pathology, Hacettepe University, School of Medicine, Ankara, Turkey

A patient is described who had a solitary left frontal intracranial chondroma originating from the falx cerebri. The tumor was totally removed. The diagnostic value of computerized tomography and the surgical findings in this rare pathological condition are discussed.

KEY WORDS - chondroma - computerized tomography - intracranial tumor • falx

$\mathrm{C}$ HONDROMAS are benign tumors that may be found in any part of the body; however, tumors of cartilaginous origin are very rare among intracranial neoplasms. ${ }^{31}$ Intracranial chondroma was first reported by Hirschfield in 1851, according to Chorobski, et $a l .{ }^{8}$ Since then, several reports have appeared, ${ }^{8,12,24}$ in which most of the tumors arose from the base of the skull. ${ }^{6,12,17,24,27}$ Localization in other parts of the intracranial cavity, such as in the frontoparietal, ${ }^{8}$ intraventricular, or parasagittal $^{3}$ regions, is rare.

We present a case of a solitary intracranial chondroma arising from the falx cerebri. The diagnosis, surgical results, and follow-up findings of this pathological condition are discussed.

\section{Case Report}

This 39-year-old man was admitted complaining of headaches and seizures. He had experienced seizures for 4 years and headaches for 2 years. Neurological examination was entirely negative except for bilateral papilledema. Plain roentgenograms were normal. Computerized tomography $(C T)$ revealed a large irregularly calcified intracranial mass in the left frontal region in close proximity to the frontal bone, but there was no bone destruction or hyperostosis. Enhancement with contrast material showed no difference in the size but a very slight increase in the density of the mass (Fig. 1). Left carotid angiography showed downward displacement of the left anterior cerebral artery by an avascular left frontal parasagittal mass (Fig. 2). The mass was diagnosed preoperatively as a left frontal parasagittal meningioma.

Left frontal craniotomy revealed intact bone and dura. On reflection of the dura, the surface of an opalescent white tumor was revealed. The tumor could easily be separated from the brain and completely removed together with its attachment to the falx cerebri. The patient's postoperative course was satisfactory and he was discharged on the 10th postoperative day without any complaint or pathological finding.

Microscopically, the tumor consisted of a fine fibrous capsule surrounding lobules of well differentiated car-

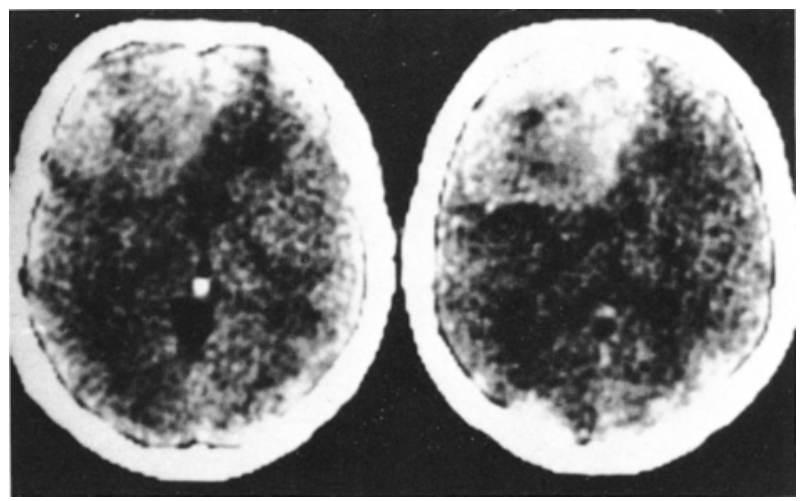

FIG. 1. Computerized tomography scans showing a solid giant left frontal mass. 


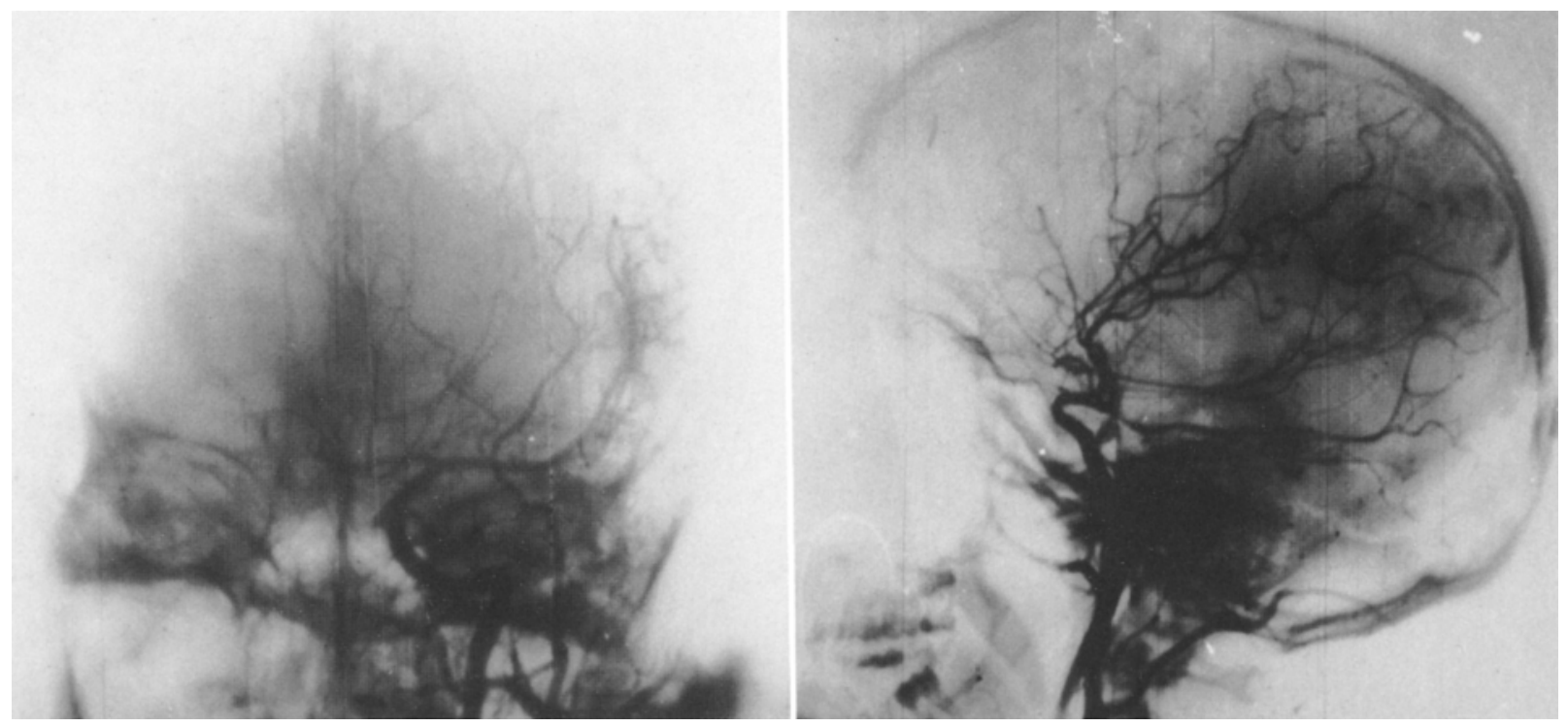

Fig. 2. Left carotid angiography, anteroposterior (left) and lateral (right) views, showing downward displacement of the anterior cerebral artery, indicating an avascular frontal parasagittal mass.

tilaginous tissue. The chondrocytes were situated in an abundant chondroid matrix, and showed no evidence of atypical cells, multinucleation, or mitotic activity (Fig. 3).

One year after surgery the patient was found to be asymptomatic. Follow-up CT revealed left frontal atrophy (Fig. 4). Four years after surgery the patient remains neurologically normal.

\section{Discussion}

Intracranial chondromas are rare. In Cushing's series of 2023 intracranial tumors, ${ }^{9}$ only three were osteochondromas. Leitholf ${ }^{23}$ found four chondromas among 4135 brain tumors at the Serafimer-Lasarettet in Stockholm, and Kleinsasser and Friedmann ${ }^{20,21}$ discovered nine chondromas in a series of 6000 intracranial tumors. Intracranial chondromas can be either solitary or a component of Ollier's multiple enchondromatosis. Solitary intracranial chondromas are usually located at the base of the skull. ${ }^{1,3-7,10-12,14,17,22,24,25,27,29,30}$ Tumors arising from the dura, ${ }^{26,28}$ choroid plexus, leptomeninges, ${ }^{13}$ or within the brain parenchyma ${ }^{2,18}$ are less common. Berkmen and Blatt ${ }^{7}$ collected 113 cartilaginous tumors from the literature, with only seven arising from the falx.

The etiology of intracranial chondromas with no attachment to the basal bones, such as those arising from the ventricles or falx, is not clearly established. The cause of these tumors was attributed to metaplasia by Chorobski, et al., ${ }^{8}$ and Forsythe, et al. ${ }^{13}$ Russell and
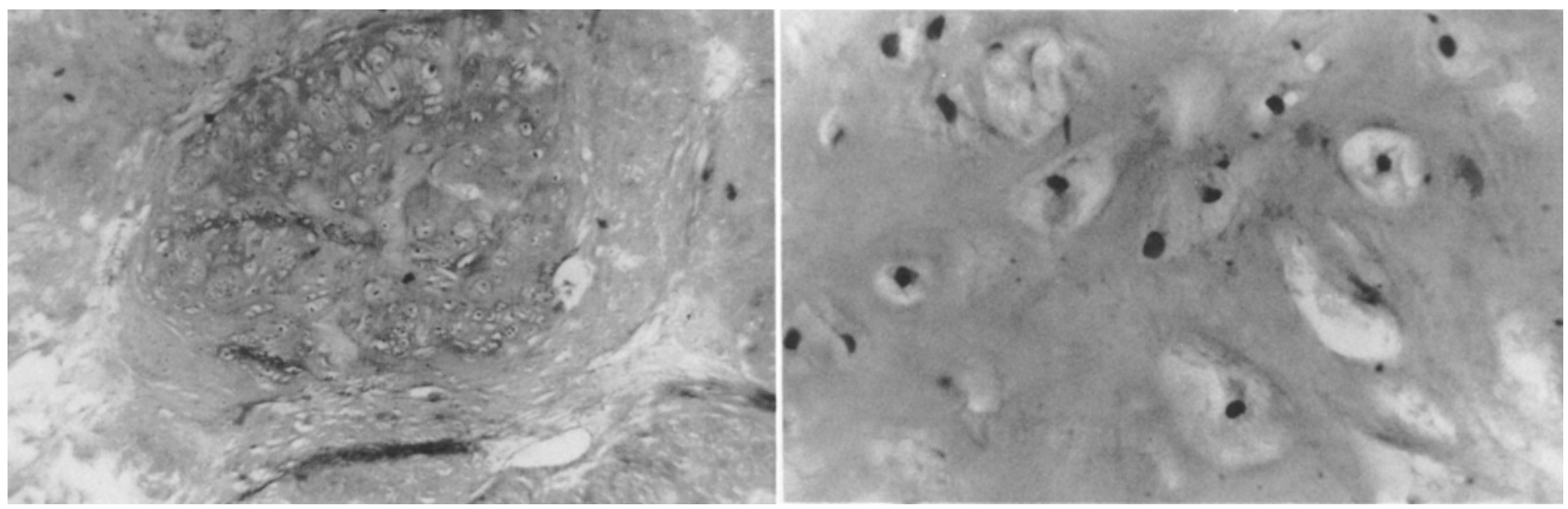

FIG. 3. Photomicrographs of the tumor material consisting of well differentiated cartilaginous tissue with chondrocytes showing no unusual formation, multinucleation, or mitotic activity. $\mathrm{H} \& \mathrm{E}, \times 100$ (left) and $\times 300$ (right). 


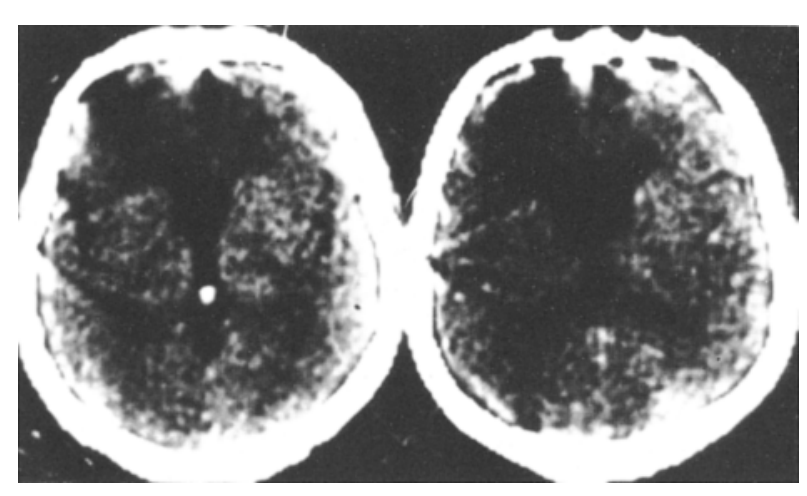

FIG. 4. Computerized tomography scans 1 year after operation showing left frontal cerebral atrophy with enlargement of the left frontal horn.

Rubinstein ${ }^{31}$ stated that aberrant rests of cartilage could lead to chondromas in parts of the intracranial cavity other than the base of the skull.

On admission, our patient was asymptomatic, apart from seizures for 4 years. Because of the slow growth of these tumors, this clinical picture is typical of chondromas. ${ }^{7,14,24}$ There is no characteristic appearance of chondromas on routine $\mathrm{x}$-ray films or angiography. ${ }^{7,27,30}$ Although a hypodense appearance on CT scans has been reported by others, ${ }^{10,15,19,20}$ CT in our patient revealed a hyperdense mass with slight enhancement.

Surgical resection is the treatment of choice in falcial chondromas. No recurrence need be expected after total removal. Our patient is symptom-free after 4 years. Hardy, et al. ${ }^{16}$ reported a patient with dural chondroma who survived for 44 years after total excision.

\section{References}

1. Acquaviva $R$, Tamic PM, Thevenot $C$, et al: Los condromas intracraneales. Revisión de la literatura a propósito de dos casos. Rev Esp Otoneurooftal 24:15-34, 1965

2. Ahyai A, Spoerri O: Intracerebral chondroma. Surg Neurol 11:431-433, 1979

3. Alpers BJ: Cerebral osteochondroma of dural origin. Ann Surg 101:27-37, 1935

4. Aronson HA, Otis RD: Intracranial chondroma involving the cerebellopontine angle. Report of a case. J Neurosurg 19:529-531, 1962

5. Bagchi AK, Sen Gupta KP: Basicranial chondromas. Int Surg 51:132-137, 1969

6. Bakdash H, Alksne JF, Rand RW: Osteochondroma of the base of the skull causing an isolated oculomotor nerve paralysis. Case report emphasizing microsurgical techniques. J Neurosurg 31:230-233, 1969

7. Berkmen YM, Blatt ES: Cranial and intracranial cartilaginous tumours. Clin Radiol 19:327-333, 1968

8. Chorobski J, Jarzymski J, Ferens E: Intracranial solitary chondroma. Surg Gynecol Obstet 68:677-686, 1939

9. Cushing H: Intracranial Tumours. Notes Upon a Series of Two Thousand Verified Cases with Surgical-Mortality Percentages Pertaining Thereto. Springfield, Ill: Charles C Thomas, 1932, pp 8, 133
10. Dutton J: Intracranial solitary chondroma. Case report. J Neurosurg 49:460-463, 1978

11. Elsberg CA: Chondroma involving the Gasserian ganglion. Ann Surg 84:887-888, 1926

12. Falconer MA, Bailey IC, Duchen LW: Surgical treatment of chordoma and chondroma of the skull base. J Neurosurg 29:261-275, 1968

13. Forsythe RW, Baker GS, Dockerty MB, et al: Intracranial osteochondroma. Proc Staff Meet Mayo Clin 22: $350-356,1947$

14. Gabrielsen TO, Kingman AF Jr: Osteocartilaginous tumors of the base of the skull. Report of an unique case and review of the literature. AJR 91:1016-1023, 1964

15. Grossman RI, Davis KR: Cranial computed tomographic appearance of chondrosarcoma of the base of the skull. Radiology 141:403-408, 1981

16. Hardy RW Jr, Benjamin SP, Gardner WJ: Prolonged survival following excision of dural chondroma. Case report. J Neurosurg 48:125-127, 1978

17. Isamat F, Miranda AM, Ripoll M: Parajugular foramen chondroma. Case report. J Neurosurg 28:490-494, 1968

18. Ishii R, Sato S, Ueki K, et al: Myxoosteochondroma in the pons. J Neurosurg 41:240-243, 1974

19. Kazner $\mathrm{E}$, Wende $\mathrm{S}$, Grumme TH: Intracranial tumours of skeletal origin, in Kazner E, Wende S, Grumme TH, et al (eds): Computed Tomography in Intracranial Tumours: Differential Diagnosis and Clinical Aspects. Berlin/Heidelberg/New York: Springer-Verlag, 1982, pp 335-338

20. Kleinsasser O, Friedmann G: Die chordome der Schädelbasis. Ein Beitrag zur Klinik, Pathologie und zur Differentialdiagnose am Röntgenbild. Dtsch $\mathbf{Z}$ Nervenheilk 177:263-285, 1958

21. Kleinsasser O, Friedmann G: Die Knorpelgeschwülste der Schädelbasis. Dtsch Z Nervenheilk 177:378-404, 1958

22. Krayenbühl H, Yaşargil MG: Chondromas. Prog Neurol Surg 6:435-463, 1975

23. Leitholf $O$ : Tumoren der Schädelknochen. Acta Neurochir $4: 287-319,1956$

24. List CF: Osteochondromas arising from the base of the skull. Surg Gynecol Obstet 76:480-492, 1943

25. Long DM, Kieffer SA, Chou SN: Tumors of the skull, in Youmans JR (ed): Neurological Surgery. Philadelphia: WB Saunders, 1982, Vol 5, pp 3227-3268

26. Mapstone TB, Wongmongkolrit T, Roessman $U$, et al: Intradural chondroma: a case report and review of the literature. Neurosurgery 12:111-114, 1983

27. Minagi $\mathrm{H}$, Newton TH: Cartilaginous tumors of the base of the skull. AJR 105:308-313, 1969

28. Palacios E: Intracranial solitary chondroma of dural origin. AJR 110:67-70, 1970

29. Richards WW, Thompson MC: Suprasellar osteochondroma with chiasmal syndrome. Arch Ophthalmol 65: $437-441,1961$

30. Roukkula M: Roentgenologic findings in chondromas of the pontine angle. Acta Radiol (Diagn) 2:120-128, 1964

31. Russell DS, Rubinstein LS: Pathology of Tumours of the Nervous System, ed 2. London: Edward Arnold, 1963, pp 54, 221

Manuscript received June 20, 1983.

Accepted in final form February 24, 1984.

Address reprint requests to: Nejat Akalan, M.D., Department of Neurosurgery, Hacettepe University, School of Medicine, Ankara, Turkey. 